\title{
Thinking Like a Mountain: Exploring the Potential of Relational Approaches for Transformative Nature Conservation
}

\author{
J. Marc Foggin $1,2, *(1)$, Daniele Brombal ${ }^{3, *(1)}$ and Ali Razmkhah ${ }^{3,4}$ \\ 1 Institute of Asian Research, School of Public Policy and Global Affairs, University of British Columbia, \\ Vancouver, BC V6T 1Z1, Canada \\ 2 Plateau Perspectives, Surrey, BC V4A 4S2, Canada \\ 3 Department of Asian and North African Studies, Ca' Foscari University of Venice, Dorsoduro 3246, \\ 30123 Venice, Italy; ali@iccaconsortium.org \\ 4 ICCA Consortium, 1186 Essertines-sur-Rolle, Switzerland \\ * Correspondence: marc.foggin@ubc.ca (J.M.F.); daniele.brombal@unive.it (D.B.)
}

Citation: Foggin, J.M.; Brombal, D.; Razmkhah, A. Thinking Like a

Mountain: Exploring the Potential of Relational Approaches for Transformative Nature Conservation. Sustainability 2021, 13, 12884. https:// doi.org/10.3390/su132212884

Academic Editor:

Panayiotis Dimitrakopoulos

Received: 14 October 2021

Accepted: 17 November 2021

Published: 21 November 2021

Publisher's Note: MDPI stays neutral with regard to jurisdictional claims in published maps and institutional affiliations.

Copyright: (c) 2021 by the authors Licensee MDPI, Basel, Switzerland. This article is an open access article distributed under the terms and conditions of the Creative Commons Attribution (CC BY) license (https:// creativecommons.org/licenses/by/ $4.0 /)$.

\begin{abstract}
Building on a review of current mainstream paradigms of nature conservation, the essence of transformations necessary for effective and lasting change are presented-namely, convivial solutions (or 'living with others'), in which relationality and an appreciation of our interdependencies are central, in contrast to life-diminishing models of individualism and materialism/secularism. We offer several areas for improvement centred on regenerative solutions, moving beyond conventional environmental protection or biophysical restoration and focusing instead on critical multidimensional relationships-amongst people and between people and the rest of nature. We focus, in particular, on the potential of people's values and worldviews to inform morality (guiding principles and/or beliefs about right and wrong) and ethics (societal rules defining acceptable behaviour), which alone can nurture the just transformations needed for nature conservation and sustainability at all scales. Finally, we systematize the potential of regenerative solutions against a backdrop of relational approaches in sustainability sciences. In so doing, we contribute to current endeavours of the conservation community for more inclusive conservation, expanding beyond economic valuations of nature and protected areas to include more holistic models of governance that are premised on relationally-oriented value systems.
\end{abstract}

Keywords: people; nature; biodiversity; conservation; regeneration; relationships; value systems; just transformations; human rights-based approaches; Indigenous Peoples and local communities

\section{Introduction}

Following the recent publication of the Intergovernmental Science-Policy Platform on Biodiversity and Ecosystem Services' (IPBES) Global Assessment Report on Biodiversity and Ecosystem Services, the loss of biodiversity is now firmly established as both severe and anthropogenically driven [1]. The main causes of biodiversity loss include pollution, overexploitation of natural resources, invasive alien species, and especially the destruction or conversion of natural habitats. Climate change also drives the loss of biodiversity. Ultimately, however, it is human population growth and our exponentially increasing consumption that may rightly be seen as the primary driver of all of the above, or as the main basis of our major impact on the biosphere. Furthermore, this loss can no longer be seen as occurring just somewhere 'out there'; it is now seen close to home and should concern everyone, everywhere - at least to the same extent as climate change, as biodiversity underpins all life on Earth. Indeed, the loss of biodiversity is now recognized not only as just one among many sectoral concerns of interest mainly to environmentalists, but as a fundamental issue for human development [2].

Maintaining biodiversity and ecosystems in a healthy condition, neither destroyed nor degraded, is also essential for the proper realization of fundamental human rights, 
including rights to life, health, food, water, and sanitation [3], based on the understanding that the access to and use of biodiversity are essential for humans' livelihoods and wellbeing, in much the same way as socioeconomic, cultural, political, and other internationally agreed rights.

Drawing from a wide range of sustainability and human rights debates [3,4], the Human Rights Council (HRC) of the United Nations has recognised and emphasised this point in its recent resolution on the "Promotion and protection of all human rights, civil, political, economic, social and cultural rights, including the right to development". The HRC declared that "[the] loss of biodiversity and the decline in services provided by ecosystems interfere with the enjoyment of a safe, clean, healthy and sustainable environment, and that environmental damage has negative implications, both direct and indirect, for the effective enjoyment of all human rights" [5]. The significance of this resolution is especially high for Indigenous Peoples and local communities (IPLCs) whose traditions and culture, including livelihoods and food systems [6-8], are highly interconnected with the natural world, reflecting an intrinsic relationship with nature.

Against this backdrop, recent years have witnessed a widening space for critical debates about how best to envision and develop nature conservation solutions in order to mutually reinforce ecological health and human wellbeing. Most recently, these debates have embraced a systemic understanding of transformation by incorporating the role of relations, cultural practices, and mental models as deep leverage points for change [9]. We do not directly address the proximate causes of environmental degradation, nor even those of human population growth, important as they are, but instead focus on the ultimate drivers of change, in particular, human agency and the major decisions we make, i.e., how we choose to live- that is, the why or the basis upon which we make our most important decisions.

This paper intends to provide a 'state of the art' of relevant current literature that was identified through a 'snowballing technique', starting from broad entry points of sustainability ethics, people-nature relations, and transformative approaches, and then to systematize the potential of relational approaches in the context of people's values and worldviews to foster transformative nature conservation and social-ecological regeneration.

\section{Conceptual Background}

Transformation is one of the most widely used buzzwords in the community of sustainability scientists and practitioners. Over the years, a considerable effort has been made to provide blueprints for transformative change. The most consistent, durable, and visionary among these blueprints has been modelled on the basis of systems thinking as first envisioned by Donella Meadows, one the founders of sustainability science [10]. According to this conceptualization, transformation describes rapid and pervasive change, leveraging mental models (values, mind-sets, worldviews) to generate institutional ruptures across the spheres of norms and rules [11]. This approach has become increasingly influential across vast areas of sustainability science, practice, and activism, complementing the otherwise dominant role of technical and financial fixes to environmental problems. By doing so, it opens up a space for envisioning structural changes in socioeconomic and political systems, driven by ethical and spiritual understandings of reality. Indeed, transformation implies being aware that biodiversity loss, climate change, and virtually all ecological crises are logical consequences of a blind pursuit of short-term material gains and prioritizing private goals over the common good, which have historically characterized many facets of human civilization [12-15]. This calls into question another aspect closely linked to many theories of change, which we incorporate into our analysis: the goal of just transformations-ensuring distributional, recognitional, and procedural justice for all rights holders and stakeholders, also including natural (non-human) entities $[16,17]$. In the context of nature conservation, we therefore neither advocate for a 'wilderness' without people, nor consider the world we live in as an entirely 'post-wild' one in which everything is to be controlled or managed through technology and markets [18]. 
Besides a systematic review of transformations needed for nature conservation, this paper is also informed by a land ethic, based on the understanding that "a thing is right when it tends to preserve the integrity, stability, and beauty of the biotic community. It is wrong when it tends otherwise" [19] (p. 262). There is a richness in this statement, fundamentally deriving from widely held core beliefs and value systems that appeal to wide sectors of society-even though these values may not always be put into practice. From this foundation, beyond seeing land and biological communities as ecological concepts or, worse still, simply as commodities belonging to us and for our individual benefit, we further concur with the ethic that naturally flows from the above statement, namely, that "when we see land as a community to which we belong, we may begin to use it with love and respect" [19]. Thus, with Bill Reed [20], we consider the 'regeneration' of nature (rather than its commodification) as a valuable societal goal, based on an appreciation of the intrinsic or inherent value of nature and our human responsibility [21,22] along with the recognition that humans not only can and must coexist with nature, but are in fact an integral part of it and should actively sustain its flourishing and protect its "integrity, stability and beauty" [23]. In regard to global conservation dialogues today, our considered perspectives therefore move beyond Georgina Mace's [24] seminal four framings of conservation that have sequentially arisen over the past five decades (and which often overlap) - from earlier conservation rationales centred on notions of wilderness (nature for itself), to more alarmist views (nature despite people), mainly utilitarian concerns (nature for people), and finally, to a recognition of the need for coexistence (nature and people) (also see [25]). With Dave Bookless [21], we see the need to adopt less-dichotomous views of people and nature, fundamentally valuing the world around us from a "relational vision of society and ecology", leading to life-affirming engagements with other people as well as with nature, of which we are inextricably a part (people within nature).

Considering that people are relational beings [26-28], that personal and societal transformations are inexorably linked [9], and that human well-being and biodiversity cannot be dissociated from each other [1-3,29], we recognize that relational approaches must be incorporated into any guiding framework if it is to be relevant, i.e., able to impact people's values and, ultimately, behaviours for nature conservation.

\section{Mainstream Conservation Solutions}

Two main approaches for nature conservation are presently being advanced in global dialogues: first, to expand the total coverage of national and global networks of protected areas, and second, to create or promote accounting systems that more adequately recognize the economic value of nature. The first approach is epitomized by initiatives such as Half Earth, the Global Deal for Nature, and the Global Safety Net [30-33], while the second paradigm underpins a wide range of practices that broadly fall under the rubric of NatureBased Solutions [32,34-37] and which are generally contingent on economic valuations of the goods and services provided by nature (aka biodiversity and ecosystem services). In recent years, many institutions and public-private networks have been established on the promise that redirecting large-scale financial flows towards nature conservation activities will be positive for both biodiversity and people-including the High Ambition Coalition for Nature and People (HAC), the Network for Greening the Financial System (GFS), the Legacy Landscape Fund (LLF), the Task Force on Nature-related Financial Disclosures (TNFD), and the International Climate Initiative (IKI). Most of these global north-based institutions also promote and actively support initiatives, such as protecting 30 percent of Earth's total land area by 2030 (the global "30 $\times 30$ target"), despite concerns expressed in multiple quarters, especially in regard to rights (see, e.g., [38-40]).

What is most concerning about the two main (so-called) 'solutions' currently being offered to reduce and, ideally, halt the loss of biodiversity, is that they are premised on two problematic tendencies: essentially seeing human and nonhuman worlds as largely incompatible rather than interdependent (cf. people within nature), and limiting our assessments of worth mainly to the realm of economics. Such solutions do not always work [41]. In 
fact, even with some pragmatic (potential) gains for environmental conservation in today's economics-oriented world, it is with genuine concern that Robert Fletcher and colleagues point out that, while there are useful elements in each of the above approaches, they almost always "fail to acknowledge and [ultimately to] confront the connection between capitalism and the profound sense of alienation from nonhuman nature on which [capitalism] grounds human experience" [42]. However, capitalism built on (a-relational) individualism and narrow private interests is not the only paradigm available to us [13].

A disconnect between people and nature in today's modern and post-modern societies is deeply ingrained, despite the recognition that social and ecological systems are entirely integrated. Moreover, problems arise when decisions are made from the basis of a thinking that presupposes a substantial priority for the economic versus other forms of wealth, especially when this translates to a belief (explicit or implicit) that continued economic growth is a necessity for human well-being, which, arguably, is one of the main root causes and drivers of environmental destruction around the world and also contributes to many of the world's socioeconomic inequities. This line of reasoning is explored at greater length in Charles Eisenstein's insightful book Sacred Economics: Money, Gift and Society in the Age of Transition, where he highlights the extent to which disconnects between people have led to socioeconomic disparities, particularly as they move away from homes and known places with all their long-standing social ties to new spaces and environments with little or no sense of community [27]. Whether we consider lost connections amongst people, or between people and the rest of nature, it is when the relational aspects of our lives are lost that we suffer most. We do not live or exist in isolation but are, in fact, known, and to a great extent, defined by our relationships with others and the world we live in $[26,43,44]$.

\section{Towards a Relational Approach for Transformations}

In light of this critique, the conservation community would do well to explore other available models that may help overcome the gridlock of modernist human-nature dichotomies and the capitalism-driven overexploitation of resources. Kate Raworth's approach to embedding economics within social and ecological boundaries advances well in this direction [45] by rejecting the premise that viable conservation solutions may only be found in a-relational contexts, whether this be by identifying humans as completely distinct and/or apart from nature, or by committing to economics-driven valuations of nature over and above the appreciation of other values, including intrinsic values. Indeed, solutions that diminish life to superficial economic transactions will not succeed in the long run. Although they may, in some circumstances, appear to be making progress, such advances will almost certainly only be 'succeeding' at the expense of other diminished lives elsewhere [46]. Additionally, the idea that people are always or are necessarily bad for nature must change, as this is patently untrue and has led to many injustices [47-50]. Instead, conservation should be transformed towards more collaborative and rights-based approaches [51], leveraging the wide range of formal (rules, organizations) and informal (values, worldviews, morals) institutional features that enable human-nature coexistence [52,53].

This requires acknowledging that, ultimately, sustainability is less of a matter of technical or managerial concern (i.e., what is done) and more of a human or social issue (who decides, and why). Sustainability is never achieved by simply knowing more about the ecology or by identifying better ways to encourage people to make the 'right decision'. The key issues to address are often the motivations behind individual and collective choices, i.e., the values, worldviews, and moral judgements that inform people's decisions and actions [54]. Place (where) also is important, as local realities deserve to be considered in detail to overcome the modernist paradigm of one-size-fits-all solutions [13]. Instead, we should move forward in ways that promote the core values of diversity and inclusion, advance locally designed solutions, and-perhaps most importantly-consider wealth as much more than just monetary value. Furthermore, health must be considered, not only in regard to people, but for the environment as a whole, including both human and nonhuman species. This latter aspect has become even more evident in the wake of the 
COVID-19 pandemic, which has highlighted the need to pursue a more comprehensive One Health approach $[29,55,56]$.

Such perspectives and directions are partially acknowledged by some elements of the global conservation community. In a recent discussion paper commissioned by the International Union for Conservation of Nature (IUCN) and its Commission on Ecosystem Management (CEM) in preparation for the 2021 World Conservation Congress, Fougères and colleagues highlight the urgent need for transformative conservation, an approach to conservation "[that] rethinks the relationships between nature, society, individuals, and risk in light of nature's contributions to people, equity and justice, and sustainable development goals [and that consequently] restructures systems to create durable change at large geographic, ecological, political-economic, and demographic scales" [9] (p. 2). Further technical reports and policy briefs calling for a greater recognition of and engagement with IPLCs in the context of global conservation goals have multiplied in 2021, especially in the lead-up to post-2020 Global Biodiversity Framework meetings [39,57-60].

Yet, despite this attention, there still remains a need to further assess and streamline the potential of several aspects of the proposed transformations, namely, the reasons or rationales underpinning injunctions for equity, justice, relational fairness, etc. Specifically, the place and role of worldviews, values, and place-based perspectives and practices are often only loosely defined or overlooked. However, recognized relational approaches to sustainability offer a platform and a means to systematize these critical aspects of change and frame their contribution to transformative conservation in a coherent way. Relational approaches in conservation embrace ethics and culture as leverage points to promote human-nature coexistence, seen particularly in the people within nature perspective, interacting with sociocultural and spatio-temporal realities for shaping a novel culture-society-nature nexus.

West et al. [61] recently advanced a framework aiming to elucidate the logic of relational approaches, highlighting complementarities with traditional approaches in the sustainability sciences and identifying important fields of application (Figure 1, adapted from [61]). Their proposition resonates with the cultural and psychological aspects of systems thinking by endorsing (a) the view that humans are part of nature, not separate from it; (b) the performative roles of culture, language, and social concepts/constructs in guiding behaviours according to perceived realities; and (c) the potential of moral frames of reference and the resulting ethics to affect and transform conditions and relationships in socio-ecological realms. In so doing, West et al. look to values and worldviews, as well as place-based perspectives and practices, to trigger and sustain the key dynamics of systemic change.

Based on West et al.'s framework [61], and by building upon our own experiences across several continents and numerous socio-cultural contexts, both Indigenous and nonIndigenous, we have identified four emergent themes that we believe are of great relevance for transformative conservation: (a) individual values; (b) cultural worldviews; (c) the intersection of morality and politics; and (d) place-based biocultural practices.

The first two themes that we shall focus on are tightly interconnected, with the directionality of connection being very difficult to ascertain as individuals are influenced by their surrounding culture; yet, simultaneously, culture itself is an emergent property of the shared experiences of communities-themselves being comprised of individuals, or people-in-relationships - with culture and people's sense of identity developing over time, based on shared histories as well as common visions and aspirations for the future. For its part, the third theme pertains to the application of individual and collective beliefs about how things should be-i.e., about right and wrong, or morality - to societal systems, structures, and rules. Put differently, this theme may also be seen as ethics expressed through politics. Finally, in the fourth theme, we aim to capture all of the previous as they play out in particular contexts, specifically in places that have not yet been so deeply affected by globalisation - whether through remoteness or resistance - or, if affected by globalisation (as nearly everywhere), then places where communities seek to continue living largely as they have for generations, not wishing to become so deeply consumed 
by materialistic and individualistic (i.e., less-relational, a-relational) tendencies, instead centring one's sense of wellbeing and wealth on relationships, both with people and with the rest of nature. In many instances, relationality-centred worldviews and politics are found amongst Indigenous Peoples (even if not exclusively so); it is lessons from such societies, learning from their biocultural practices, that we wish to humbly consider here.

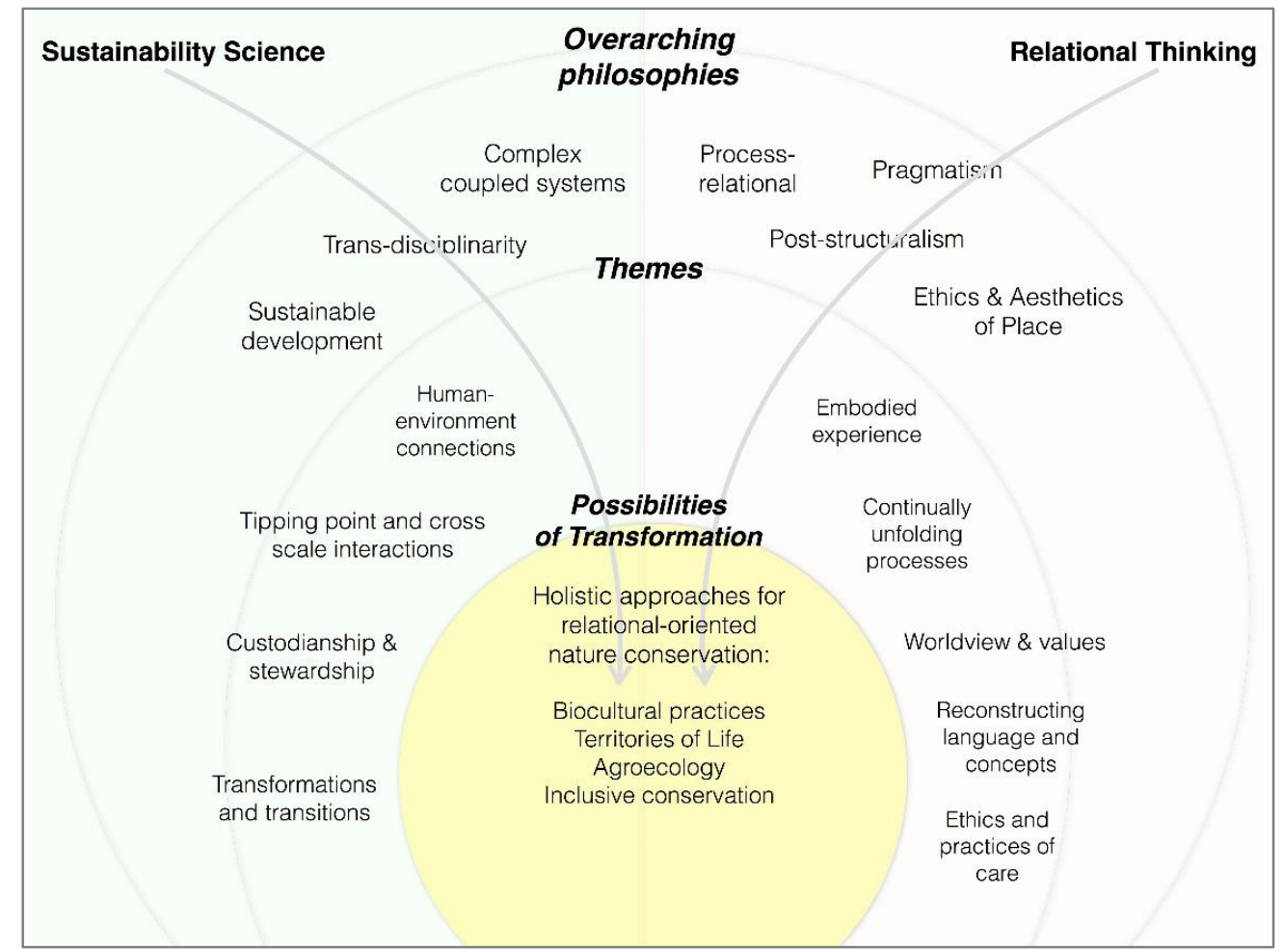

Figure 1. Streamlining Relational Approaches to Sustainability (source: authors; inspired by [61]).

In the following section, we review the contribution of each of these emerging themes as they pertain to possible alternatives to current patterns and practices in nature conservation. These are then followed by a discussion of their implications for science, policy, and practice in biodiversity conservation, and, more broadly, for matters of sustainability.

\section{Relational Pathways for Transformative Conservation}

\subsection{Individual Values}

What we value clearly affects our choices and actions. Values can be understood as "a desirable trans-situational goal [...] which serves as a guiding principle" for individuals and groups [62] (p. 21). Over time, amplified by the world's ever-growing human population and increasing demands for more products and services, all our individual choices - in the marketplace, transportation, agriculture, and leisure-collectively affect global sustainability.

Oddly, there seems to be a strong belief, both in academia and with the general public, that the current dominant economic system is the only possible system, and this therefore remains the primary basis for most normative ideas of what is desirable and what is not. However, a growing number of economists and social scientists are beginning to highlight the plurality of tried and tested alternatives that are already present. GibsonGraham and Dombroski, for example, offer us "a head-on challenge to narratives that valorize a monolithic neoliberal capitalism and [its] assumed benefits [despite all of] the social inequities and degraded ecologies it produces ... ". They note, in particular, that although "capitalism appears to many as a system that is here to stay and to which 'there is no alternative' ... a different way forward [is possible, as testified by] the diversity of economic practices that ... make up our shared world" [13]. They present a range 
of strategies "for 'doing economy' differently," ways where the economy is diverse and heterogeneous rather than fixed in form. The truth of the matter is that what we believe about nature and our place in it and what we assume to be constraints in the current socioeconomic systems will limit the scope of our vision for the future-likely blinding us to what could be better ways forward.

Recently, Fletcher and colleagues have offered a dozen basic principles [42] for moving into a post-growth world with more inclusive perspectives on health and wellbeing-for both people and nature. An abridged and adapted selection of these is presented in Table 1.

Table 1. Key Principles for Conservation in a Post-Growth World (adapted from [42]).

\begin{tabular}{|c|c|c|}
\hline $\begin{array}{c}\text { Major } \\
\text { Principles }\end{array}$ & Brief Description of Each Principle & $\begin{array}{c}\text { Key } \\
\text { References }\end{array}$ \\
\hline Diversity & $\begin{array}{l}\text { In addition to biological diversity, people and communities exhibit a diversity } \\
\text { of cultures, polities, and economies together with different ways of being, } \\
\text { knowing, doing, and visioning. Diversity of languages is equally crucial to our } \\
\text { understanding and dealing with many of the issues facing humanity, as every } \\
\text { language encompasses vast libraries of local and traditional knowledge. }\end{array}$ & [63-67] \\
\hline Conviviality & $\begin{array}{l}\text { Moving beyond 'protected areas' as the main form of conservation, } \\
\text { conviviality prioritizes development of more integrated spaces in which both } \\
\text { humans and non-human species can respectfully and equitably co-exist. } \\
\text { People and wildlife will not always occupy the exact same spaces; rather, } \\
\text { diverse landscape matrices are envisaged. Greater equity and inclusivity } \\
\text { amongst those involved in conservation and a greater diversity of governance } \\
\text { systems are also promoted through this matrix. Convivial conservation thus } \\
\text { moves beyond most other models, offering us a Whole Earth vision for } \\
\text { ecological challenges. }\end{array}$ & {$[12,68,69]$} \\
\hline $\begin{array}{l}\text { Valuing the } \\
\text { 'sacred' }\end{array}$ & $\begin{array}{l}\text { Alternative (non-economic) values also must be recognized, leading to a desire } \\
\text { amongst many Indigenous and traditional rural communities for nature } \\
\text { conservation that largely emanates from their close ties to the land and } \\
\text { relationships with the nonhuman world. These perspectives are oft-guided by } \\
\text { beliefs from the spiritual realm, with the value of nature being intrinsic and/or } \\
\text { derived from God-given worth. Much benefit can therefore accrue from } \\
\text { de-commodifying nature-i.e., no longer focusing first and foremost on } \\
\text { economic valuations and biodiversity financing, or partnering with } \\
\text { conventional extractive interests, but rather viewing conservation as a global } \\
\text { collective endeavour requiring a fair and equitable stewardship, by everyone } \\
\text { and for all life on the planet. }\end{array}$ & {$[21,27,34,40,67,70-75]$} \\
\hline
\end{tabular}

In addition to the above, but still in relation to valuing the sacred, more dominant cultures with their beliefs and core values could also be fruitfully engaged. Especially in light of the perceived failure of much of the Western world to respect nonhuman nature, mainly by instrumentalizing it [34] rather than recognizing its intrinsic and spiritual worth, and also noting a general reluctance to devolve or share power with others despite clear and strong injunctions to do so within broadly Judeo-Christian belief systems, much may be gained from taking a fresh look at and renewing discussion about matters of faith in relation to both social and environmental justice. To some extent, recent developments in pertinent global religious dialogues are promising. Pope Francis' Encyclical Laudato Sì, in particular, is clearly inspired, as it seeks to re-value human coexistence with nature-hence the promotion of a more 'integral ecology' [76] that is inclusive of both environmental and social justice in ways that are intentionally attentive to the most vulnerable: "We are not condemned to economic models whose immediate interests are limited to profit ... and are unconcerned with human, social and environmental costs. Development cannot be restricted to simply economic growth - to be authentic it must be well round and integral." [77].

Besides formal religious institutions, lay persons and academics alike in the 'West' or the 'Global North' have been establishing important and influential fora to promote 
meaningful dialogues on the role of spiritual traditions for shaping new sets of values. Engaged scholarship plays a fundamental role in this respect, such as the Yale Forum on Religion and Ecology, Religion and Conservation Biology Working Group, and John Ray Initiative connecting Environment, Science \& Christianity [78-82].

\subsection{Cultural Worldviews}

Values, in turn, underpin and inform people's worldviews, i.e., their overall beliefs and perspectives on life and the world around them, as well as their views on proper relationships between different entities and phenomena-in this case, relations between people and nature [83]. In other words, basic values are crystalized over time into worldviews that "embody our awareness of the social and natural world [and reflect] how we define good quality of life and [how we] link our present to the future that we envision" [84].

Grasping the potential of worldviews requires moving well beyond the realm of ecology and economics and into more ethical domains, also tightly connected with cultures and thus with particular people and places. This not only raises challenges with which we must contend, but also highlights for us a range of possibilities to collectively reimagine our futures. Such possibilities relate to two main points. The first has to do with relationships, i.e., how to engage with other people as well as with the nonhuman world (or as some prefer to say, the 'more-than-human' world, e.g., [17,85]; but also see [86]); the second one relates to the time horizon of our thoughts and actions.

Relational worldviews are informed by an awareness that no person really exists dis-connected from others. As human beings, we live and thrive in relationships. Without relationships, you are only a body, literally any-body. Relationships shape history and shared life; therein lies our essence, bringing to each of us our own unique flavour, and it is from these relationships - with people and with nature, and also in spiritual realms-that we emerge as human beings with unique and special cultures, living out our manifold interconnections. As was already mentioned, as we consider our relationships with 'the other', this does not focus only on other people but also on the nonhuman world and how different sociocultural groups see themselves in relation to the nonhuman world-and consequently, how we use it and/or share life with the rest of nature. Herein lies some of the most significant differences that need to be carefully negotiated as we seek common ground and agreement for the conservation of global biodiversity and for sustainability achieved with fairness and equity [87]. Herein also lies what may be one of today's inexorable problems: most of the approaches and offers for a better future through 'development' and 'sustainability' overlook the broader community of life as well as the intrinsic relational aspects of the person. Instead, they focus almost exclusively on short-term gains, on material aspects of individual life, ignoring the importance of people, communities, and cultures in favour of more tangible physical dimensions, thereby fuelling the degradation of both the non-material (e.g., persons, culture) and bio-physical world around us (i.e., the environment, livelihoods, socioeconomic conditions, etc.).

Expanding the time-horizon underpinning our worldviews is the key to overcoming this gridlock, as "stretching the mind across time can help us become more responsible planetary stewards and foster empathy across generations" [88]. Leopold's imagery of "thinking like a mountain" [19] is particularly helpful, conjuring several overlapping meanings: (a) recognizing that human civilization has coevolved with nature through thousands of years, (b) acknowledging the transient nature of most material goods, yet simultaneously acknowledging their long-lasting impacts on the biota, and (c) benchmarking our actions and envisioning our goals against a longer-range future perspective. Such perspectives on life are deeply ingrained in traditional societies but have nearly disappeared in industrialized, secular societies. Yet, they can still be evoked in most people if they are given the possibility to isolate themselves from purely secularist environments and connect with nature, to reflect on its rhythms and mechanisms and innate value, recognizing that these may resonate within their own bodies and minds (for insight on how one may facilitate such processes, see e.g., Theory-U work [89]). Such rich resonance-which is both cognitive 
and emotional-is key to transforming worldviews in ways that are consistent with the goal of the "integrity, stability, and beauty of the biotic community" [19].

\subsection{Morality and Politics}

While we may aim at the realization of a specific worldview, informed by normative and value judgments, in reality, different views of the world will always coexist in space and time. Oftentimes, these many worldviews reflect divergences occurring between different ethnic or sociocultural groups or highlight conflicting values upheld by local/rural versus more urbanized communities. Against such a background, much of today's conservation outcomes depend on the critical interactions between and across these divergent worldviews, engaging with a wide range of rights holders and other stakeholders.

In recent decades, the concept of stakeholders has led to greater diversity and inclusion in development planning and decision making. The notion has been adopted in order to recognize the full variety of actors who may legitimately have a direct interest in particular development actions and outcomes, to offer means and pathways for empowering marginalized groups, especially in the face of corporations who might otherwise simply appropriate resources for themselves without much regard for lasting social or environmental consequences. There are, however, at least two significant critiques to the broad concept of stakeholders as applied to the practice of conservation. The first relates to the fact that we largely understand "stake" as expressing an interest in a commodity that can be delimited and monetized. This is at odds with the intrinsic value of biodiversity, based on a more holistic understanding of what is important and good. The second issue lies in the current practice of conducting stakeholder assessments, whereby just about anyone who wishes to do so may lay claim to a place or resource, thereby gaining recognition and voice - being legitimized — as a stakeholder, whether or not they have had any prior interest or customary tenure (i.e., rights) in the particular context. By doing so, such actors are effectively grabbing hold of a figurative 'stake' and placing it in the ground-as in colonial American land grabs of the nineteenth century-thus claiming for themselves equal rights in ownership or access and the use of particular places or resources.

Because of this misapplication of the important notion of stakeholder, it is necessary to now also recognize the much more restrictive category of rights holders-despite the challenges that may arise, including counterclaims - and such rights should be applied and recognized for local communities, especially for Indigenous Peoples, i.e., all who have de facto conserved their lands and territories for generations, whether or not these are formally recognized by external legislative frameworks. Such special rights of Indigenous Peoples are recognized in international law [90], and are now further endorsed in relation to the right of all people to have access to biodiversity and a clean and healthy environment $[3,4,91]$. However, huge gaps remain in the capacities of Indigenous people and local communities (IPLCs) to effectively exercise these rights-especially when powerful interests claim a territory or resource, be they State or private sector interests.

In regard to global nature conservation and sustainability proposals, the fact that several major new initiatives, such as the Green New Deal (GND) and Global Safety Net (GSN), are calling for a significant expansion of the world's protected area estate may also be cause for social and ecological concerns, even if counter-intuitively at first, as over one-third of the proposed "half the planet" under such proposals overlap with traditional Indigenous lands [32,33]. Thus, matters of justice and rights are rapidly arising as more and more IPLCs are being "cornered by PAs" [92] in what amounts to an increasingly forceful application of global (or at least non-local) preferences and decisions to local people and contexts - thereby breaking virtually every principle that has been outlined in Table 1 (further complemented by Table 2, below) - in what is now recognized in some quarters as conservation imperialism or colonialism $[47,93,94]$ (but also see emerging trends that are increasingly recognizing the rights, values, and roles that could be played by IPLCs and their land areas and territories in global nature conservation [95]). 


\subsection{Place-Based Biocultural Practices}

Throughout history, we have always made use of and modified nature in response to our needs. Conversely, and at the same time, nature and the environments where we have been living have influenced and shaped our cultures, ethics, and values [113]. These have adapted to the ecological characteristics of the regions and specific places where human communities have lived. Therefore, while there is much diversity in ecosystems, climates, and biomes, there is also remarkable cultural diversity. Although this does not simply parallel the diversity found in the natural world, it is profoundly interrelated with it [113-118]. This complex interrelated system of sociocultural and biological diversity is called biocultural diversity [105]. Specifically, it "comprises the [full] diversity of life in all of its manifestations-biological, cultural, and linguistic - which are interrelated (and likely co-evolved) within a complex socio-ecological adaptive system" [6].

Table 2. Key Principles for Conservation ... (continued) (adapted from [42]).

\begin{tabular}{|c|c|c|}
\hline $\begin{array}{c}\text { Major } \\
\text { Principles }\end{array}$ & Brief Description of Each Principle & $\begin{array}{c}\text { Key } \\
\text { References }\end{array}$ \\
\hline $\begin{array}{l}\text { Democracy, justice, } \\
\text { and redistribution }\end{array}$ & $\begin{array}{l}\text { All relevant actors must be welcome and able to participate in } \\
\text { major deliberations and decision making, with rights holders } \\
\text { to be central in processes-with more than cursory } \\
\text { engagement. Recognizing the varied perspectives, needs, and } \\
\text { aspirations of all actors is of critical importance, and costs and } \\
\text { benefits must be equitably distributed. }\end{array}$ & {$[44,49,96-100]$} \\
\hline $\begin{array}{l}\text { Subsidiarity } \\
\text { principle }\end{array}$ & $\begin{array}{l}\text { The principle of subsidiarity holds that all important } \\
\text { decisions that can effectively be reached at local level should } \\
\text { be made at the local level, with higher-level processes broadly } \\
\text { supporting local autonomy and only intervening when } \\
\text { actions are needed that cannot be handled at the local level. }\end{array}$ & [101-106] \\
\hline $\begin{array}{l}\text { Global connections } \\
\text { and power relations }\end{array}$ & $\begin{array}{l}\text { An important caveat to the above principle of subsidiarity is } \\
\text { that although local communities should be supported in their } \\
\text { conservation efforts, they should not be deemed as solely } \\
\text { responsible for conservation actions and outcomes. Many of } \\
\text { the most pressing conservation threats today stem not from } \\
\text { local actors, but from much larger industrial interests and the } \\
\text { elites who direct and benefit from them-and conservation } \\
\text { attention must therefore also be directed toward them, even if } \\
\text { they live far from the conservation spaces of interest. In many } \\
\text { instances, power relations must be revisited, e.g., reversing } \\
\text { the widely held neoliberal capitalist models that are } \\
\text { transforming our planet on the premise that nature is only a } \\
\text { source of materials and economic wealth, with benefits } \\
\text { deriving but for a minority. }\end{array}$ & {$[21,27,30-32,69,97,107-112]$} \\
\hline
\end{tabular}

Western modernization has largely undermined the biocultural perspectives of many Indigenous Peoples and local communities, who hold a view of humans as part of, rather than separate from, nature [113]. Such a holistic perspective can sustain the regeneration of relations between humans and the rest of nature. We do not endorse the "noble savage myth" that portrays Indigenous Peoples as being always peaceful and inimitable friends of nature (as described by Kent Redford [119], Ter Ellingson [120], and Jared Diamond [121]). Yet, we also wish to avoid falling on the other end of the spectrum, assuming that local and Indigenous communities have nothing to speak into modern contexts, as they often, in fact, maintain rich sociocultural, ethical, and spiritual elements that can support the transitions needed for human civilization to move toward more sustainable paths [53].

In this view, the biocultural diversity of life (human and non-human) holds intrinsic value and ought to be conserved [122], and the concept of conservation appropriately 
"reminds us of our duties to nature and the future, without which the pace of economic growth will merely be a measure of the speed at which we approach the abyss" [123].

Because of this, write Frank Chuang and his co-authors, so-called "elegant solutions" that adopt "single problem-single solution approaches" to reach sustainability goals that are held by some but not others are no longer satisfactory: "to address 'wicked problems' (which literally all sustainability issues belong to) involving multiple rationalities ... cultural theorists [now] propose clumsy solutions [wherein] all voices should be heard and responded to by the others" [84]. However, IPLCs still find themselves often coming from marginalised positions and perspectives, relative to much of the world's current dominant socio-economic systems.

More positively, recent development dialogues are now beginning to point out the need for greater recognition, appreciation, and understanding of local, traditional, and Indigenous ways [38]. However, enhanced understanding and dialogue amongst and between Indigenous people and local communities, on the one hand, and with more dominant cultures with larger populations, on the other hand, are still sorely needed, not so much to convert people to others' views and/or ways, but simply to provide the space needed for fair and constructive discussions, and sometimes debates, so that we may find better ways to enhance collective well-being and global sustainability together. However, for such a grand endeavour to succeed, we first need to recognize that beliefs and values really do matter — that culture matters [124] — and secondly, that stakeholders' views and values must be examined with clarity, unearthing and prioritizing those visions that can steer today's broadly interconnected world towards a sustainable path.

As agreed in most ethical and faith/belief systems, considering and treating others and, indeed, all of nature in light of intrinsic worth, not exploiting them but seeing all as fellow living beings worthy of respect and concern, ought to be the norm. If lived out, this would lead to vastly different social and environmental outcomes than are seen in practice today. Many Indigenous Peoples clearly recognize and live by these relational values. Most of the world's larger monotheistic faiths also acknowledge such values (see e.g., [125]), even if many nominal or less-informed adherents frequently live otherwise.

As a subset of the above, much applied study could be profitably made in the social sciences and the humanities, in philosophy, and in theology/spirituality, to identify the transformative potential inherent in biocultural perspectives held by different stakeholders. A number of works are already addressing these critical issues, including the relationship between conservation and ICCAs or 'territories of life' $[26,48,49,126]$, yet much still remains to be done. As is outlined from several angles throughout this paper, what people believe and what they value have implications for their actions-and consequently, for development and conservation outcomes. In an integrated world, people's views and their ways of living, even far away from spaces of interest for conservation, are now affecting local contexts and people. Therefore, broadening our overall knowledge and understanding of worldviews at all scales remains essential for achieving sustainability, including a better understanding of IPLCs and biocultural diversity.

Returning again to Indigenous ways of perceiving and knowing the world, we can hear them speak for themselves in the Suusamyr Declaration, prepared by representatives from over 50 communities who gathered from around the world in 2018:

As members of ancient cultures who possess and maintain a wealth of knowledge, practices and strategies on how to live in harmony with nature, we reaffirm that any solution to the climate crisis must be mindful of the deep relationship between human communities and biological diversity as it forms the physical and spiritual basis of our existence. The future of mountain indigenous peoples depends above all on maintenance of the sacred relationship between our cultures and water, air, plants, pastures, animals, mountains ... [127].

Globally, Indigenous Peoples make up less than $5 \%$ of the world's total human population. Nevertheless, they manage or have land tenure rights over a quarter of the world's land area, representing close to $80 \%$ of the planet's biodiversity $[67,96]$-and 
we would do well to collaborate with them and their close ties to the land for achieving local and global conservation goals [48,49,100,128-130]. Recognizing the value of place-based biocultural perspectives is thus critical for biodiversity conservation and sustainability $[44,64,66,131-133]$ and these should be more appropriately incorporated into development studies. This requires a complex but necessary balance between nature conservation and human development [122]. Such a view could be a possible answer to Leopold's challenging question: how can we humanely occupy the Earth without rendering it dysfunctional? The ethical viewpoint of the biocultural perspective is that when we have any real concerns about potential risks to nature, a precautionary approach must be taken [6].

\section{Conclusions-Implications for Knowledge and Action}

From an ethical standpoint, sustainability is not simply an environmental issue. With the ongoing COVID-19 pandemic, and with its devastating impacts expected to remain with us for many years ahead, now is a time for reflection, as it is also a time for rest or sabbath, even offering us a sort of 'reset' function, thereby enabling us to again reconsider the future we want. Rethinking many of our most basic assumptions is long overdue-not least about the worth that we attribute to things, the value of local versus global, and the relationships both between people and with the nonhuman world. To trigger systemic change, more important than identifying 'technical or managerial fixes' for perceived problems, it is critical that we begin to more deeply reconsider the values and politics informing our choices, both as individuals and as communities and societies. Doing this by adopting a relational approach means engaging with the people and groups who are most fundamentally affected by decisions and with the unique characteristics of place [134] — with place understood as the space where relationships amongst people and with nature develop and where their legacy remains through time. Sustainability is always related to people as much as it is with nature, and it is also embedded in place, since people live and make their most important decisions within particular areas and territories and within communities, never simply by way of abstract economic algorithms. As we consider the massive scale and scope of conservation challenges for the next 10 years and beyond, the strategies that may best promote fruitful actions and build commitments to achieve effective and fair conservation outcomes rest in these realms, not in the standard attempts to gain more knowledge about biodiversity or ecology solely to design technical fixes, nor in the economic models we assume should coerce otherwise unwilling stakeholders to align their actions with our interests in biodiversity conservation and people's and nature's rights. Thus, in research as in advocacy and policy, we must focus more attention on people, selves included, and especially on the transformative potential of culture, ethics, and spirituality [34].

What does this mean for key territories for nature conservation specifically? The future of these territories rests, more than anything else, on deepening our understanding of their social dimensions and seeing them not merely as integrated systems with local dynamics, but also as being embedded in a globalized world. Almost always, studying governance in these areas, including governance by local/Indigenous people of their community's conserved areas, will also offer us fruitful learnings that can be brought over into the wider sphere of global nature conservation. All we need to bring is the humility to recognize the importance of these critical issues, the genuine desire to learn from others, and a sincere willingness to act and, if necessary, to change.

Current dominant industrial and globalized worldviews have seen changes in values and attitudes, especially in recent generations, with a substantial weakening of former nature-human connectedness, jeopardizing our collective opportunity to protect the "integrity, stability and beauty of the Earth" [19]. We need to understand, as Harmon [115] mentions, that "diversity in nature and culture makes us human" — since we are as much relational beings as we are material beings. Upholding pathways for human-nature connectedness may even be a precondition for bringing about transformative change. 
As the patron saint of environmentalists, Rachel Carson, wisely highlighted in her last work - The Sense of Wonder, published posthumously in 1965 [135] - prolonged and close interaction with nature can enable knowledge, moral clarity, and caring attitudes towards the world around us. It is through contact-not separation-that we may come to see things from a different perspective. Restricting our interaction with nature, enclosing ourselves in a technological bubble so that things can keep going in a business-as-usual modality would drive us in the opposite direction.

'Thinking like a mountain' rests on seeing the world as a mountain does-considering the whole environment (i.e., people and nature, and indeed people within nature) through the prism of place, with people, and seeing nature through longer time frames and with an appreciation for beauty in the great diversity and complexity of life. To this end, further exploration and research about those value systems is recommended-such as con viva, buen vivir, ubuntu, and a wide range of reciprocity-based systems-which may provide inspiration for transformative agendas. Greater acceptance of Indigenous and traditional ways along with informed dialogues pertaining to rights are a part of this. In short, "relationships matter [and] conservation outcomes will be maximized to the extent that we recognize the critical nature and role of community and culture in conservation [... ] and realize that choices and actions are always based on the values that we hold" [28]. In our quest to restore our relationship with nature, local/traditional communities and Indigenous Peoples can provide many tangible examples of more inclusive relationships-both amongst human societies and with the rich and vibrant nonhuman world-pointing toward a more sustainable path.

Author Contributions: Conceptualization, J.M.F. and D.B.; writing—original draft preparation, J.M.F.; writing — review and editing, J.M.F., D.B. and A.R.; visualization, D.B. and A.R. All authors have read and agreed to the published version of the manuscript.

Funding: This research received no external funding.

Institutional Review Board Statement: Not applicable.

Informed Consent Statement: Not applicable.

Data Availability Statement: Not applicable.

Acknowledgments: The authors gratefully acknowledge the support of their respective institutions, including the Institute of Asian Research in the School of Public Policy and Global Affairs, UBC, (Vancouver, Canada) where this work was initiated (J.M.F.); the Department of Asian and North African Studies, Ca' Foscari University of Venice (Venice, Italy) (D.B., A.R); The European Institute for Chinese Studies (EURICS) in Paris, France (D.B.); ICCA Consortium (global network) (A.R., J.M.F.); and Plateau Perspectives, (South Surrey, Canada) which has enabled the first author to directly engage with many of the critical issues raised in this article, first-hand, through a wide range of field-based environmental projects, academic research, and diverse multicultural partnerships over the past two decades.

Conflicts of Interest: The authors declare no conflict of interest.

\section{References}

1. IPBES. Global Assessment Report on Biodiversity and Ecosystem Services of the Intergovernmental Science-Policy Platform on Biodiversity and Ecosystem Services; IPBES Secretariat: Bonn, Germany, 2019. Available online: https://ipbes.net/global-assessment (accessed on 11 November 2021).

2. Roe, D.; Seddon, N.; Elliott, J. Biodiversity Loss Is a Development Issue. A Rapid Review of the Evidence; International Institute for Environment and Development (IIED): London, UK, 2018; p. 14. Available online: https://pubs.iied.org/17636iied (accessed on 11 November 2021).

3. Knox, J.H. Framework Principles on Human Rights and the Environment; The Main Human Rights Obligations Relating to the Enjoyment of a Safe, Clean, Healthy and Sustainable Environment; The Office of the High Commissioner for Human Rights (OHCHR): Geneva, Switzerland, 2018. Available online: https:/ / undocs.org/A/HRC/37/59 (accessed on 11 November 2021).

4. Boyd, D.R.; Keene, S. Human Rights-Based Approaches to Conserving Biodiversity: Equitable, Effective and Imperative. A Policy Brief from the UN Special Rapporteur on Human Rights and the Environment; The Office of the High Commissioner for Human Rights (OHCHR): 
Geneva, Switzerland, 2021. Available online: https://www.ohchr.Org/Documents/Issues/Environment/SREnvironment/ policy-briefing-1.pdf (accessed on 11 November 2021).

5. Human Rigths Council. Promotion and Protection of All Human Rights, Civil, Political, Economic, Social and Cultural Rights, Including the Right to Development; A/HRC/48/L.23/Rev.1. 5 October 2021. Available online: https://undocs.org/a/hrc/48/1. 23/rev.1 (accessed on 11 November 2021).

6. Maffi, L. Biocultural Diversity and Sustainability. In The SAGE Handbook of Environment and Society; SAGE Publications Ltd.: London, UK, 2007; pp. 267-277. [CrossRef]

7. Hodges, J.; Foggin, J.M.; Long, R.; Zhaxi, G. Globalisation and the sustainability of farmers, livestock-keepers, pastoralists and fragile habitats. Biodiversity 2014, 15, 109-118. [CrossRef]

8. Foggin, J.M.; Emslie-Smith, M.; Hergarten, C. Food Systems and Agrobiodiversity in the Mountains of Central Asia. Mt. Res. Dev. 2018, 38, 175-179. [CrossRef]

9. Fougères, D.; Andrade, A.; Jones, M.; McElwee, P.D. Transformative Conservation in Social-Ecological Systems; IUCN Commission on Ecosystem Management (CEM): Geneva, Switzerland, 2020. Available online: https://www.iucn.org/sites/dev/files/content/ documents /cem_2020_-_transformative_conservation.pdf (accessed on 11 November 2021).

10. Blythe, J.; Silver, J.; Evans, L.; Armitage, D.; Bennett, N.J.; Moore, M.; Morrison, T.H.; Brown, K. The Dark Side of Transformation: Latent Risks in Contemporary Sustainability Discourse. Antipode 2018, 50, 1206-1223. [CrossRef]

11. Brombal, D. Is fighting with data enough? Prospects for transformative citizen science in the Chinese Anthropocene. J. Environ. Plan. Manag. 2020, 63, 32-48. [CrossRef]

12. Büscher, B.; Fletcher, R. Towards Convivial Conservation. Conserv. Soc. 2019, 17, 283. [CrossRef]

13. Gibson-Graham, J.K.; Dombroski, K. Introduction to The Handbook of Diverse Economies: Inventory as Ethical Intervention. In The Handbook of Diverse Economies; Edward Elgar Publishing: Cheltenham, UK, 2020; pp. 1-24. [CrossRef]

14. Feola, G. Societal transformation in response to global environmental change: A review of emerging concepts. Ambio 2015, 44, 376-390. [CrossRef]

15. Feola, G. Capitalism in sustainability transitions research: Time for a critical turn? Environ. Innov. Soc. Transit. 2020, 35, 241-250. [CrossRef]

16. Bennett, N.J.; Blythe, J.; Cisneros-Montemayor, A.M.; Singh, G.G.; Sumaila, U.R. Just Transformations to Sustainability. Sustainability 2019, 11, 3881. [CrossRef]

17. Braidotti, R. The Posthuman; Polity Press: Cambridge, UK, 2013.

18. Massarella, K.; Nygren, A.; Fletcher, R.; Büscher, B.; Kiwango, W.A.; Komi, S.; Krauss, J.E.; Mabele, M.B.; McInturff, A.; Sandroni, L.T.; et al. Transformation beyond conservation: How critical social science can contribute to a radical new agenda in biodiversity conservation. Curr. Opin. Environ. Sustain. 2021, 49, 79-87. [CrossRef]

19. Leopold, A. A Sand County Almanac: And Sketches Here and There; Oxford University Press: Oxford, UK, 1949.

20. Reed, B. Shifting from 'sustainability' to regeneration. Build. Res. Inf. 2007, 35, 674-680. [CrossRef]

21. Bookless, D.J.C. Why Should Wild Nature Be Preserved? A Dialogue between Biblical Theology and Biodiversity Conservation. Ph.D. Thesis, University of Cambridge, Cambridge, UK, 2019. [CrossRef]

22. Adams, W.M. The value of valuing nature. Science 2014, 346, 549-551. [CrossRef] [PubMed]

23. Leopold, A.C. Living with the Land Ethic. BioScience 2004, 54, 149-154. [CrossRef]

24. Mace, G.M. Whose conservation? Science 2014, 345, 1558-1560. [CrossRef] [PubMed]

25. Fletcher, M.-S.; Hamilton, R.; Dressler, W.; Palmer, L. Indigenous knowledge and the shackles of wilderness. Proc. Natl. Acad. Sci. USA 2021, 118, e2022218118. [CrossRef]

26. Sajeva, G.; Borrini-Feyerabend, G.; Niederberger, T. Meanings and More ... Policy Brief of the ICCA Consortium no. 7. ICCA Consortium in Collaboration with Cenesta, Tehran, Iran, 2019. Available online: https:/ /www.iccaconsortium.org/index.php/20 11November25/icca-consortium-policy-brief-no-7-meanings-and-more (accessed on 11 November 2021).

27. Eisenstein, C. Sacred Economics: Money, Gift, and Society in the Age of Transition. Evolver Editions: Berkeley, CA, USA, 2011. Available online: https:/ / sacred-economics.com/read-online/ (accessed on 11 November 2021).

28. Foggin, J.M. We still need the wisdom of Ubuntu for successful nature conservation. AMBIO A J. Hum. Environ. 2021, 50, $723-725$. [CrossRef]

29. Seymour, V. The Human-Nature Relationship and Its Impact on Health: A Critical Review. Front. Public Heal. 2016, $260,1-12$. [CrossRef]

30. Wilson, E.O. Half Earth: Our Planet's Fight for Life; Liveright Publishing Corporation: New York, NY, USA, 2016.

31. Dinerstein, E.; Vynne, C.; Sala, E.; Joshi, A.R.; Fernando, S.; Lovejoy, T.E.; Mayorga, J.; Olson, D.; Asner, G.P.; Baillie, J.E.M.; et al. A Global Deal For Nature: Guiding principles, milestones, and targets. Sci. Adv. 2019, 5, eaaw2869. [CrossRef] [PubMed]

32. Dinerstein, E.; Joshi, A.R.; Vynne, C.; Lee, A.T.L.; Pharand-Deschênes, F.; França, M.; Fernando, S.; Birch, T.; Burkart, K.; Asner, G.P.; et al. A "Global Safety Net" to reverse biodiversity loss and stabilize Earth's climate. Sci. Adv. 2020, 6, eabb2824. [CrossRef]

33. Asner, G. Protecting Half of the Planet is the Best Way to Fight Climate Change and Biodiversity Loss-we've Mapped the Key Places to Do It. The Conversation Newsletter, 2020. Available online: https:/ / bit.ly/3Dz2CfL (accessed on 11 November 2021).

34. Martin, J.-L.; Maris, V.; Simberloff, D.S. The need to respect nature and its limits challenges society and conservation science. Proc. Natl. Acad. Sci. USA 2016, 113, 6105-6112. [CrossRef] 
35. Cohen-Shacham, E.; Walters, G.; Janzen, C.; Maginnis, S. (Eds.) Nature-Based Solutions to Address Global Societal Challenges; IUCN International Union for Conservation of Nature: Gland, Switzerland, 2016.

36. Sylvén, M.; Martin, V. Nature-Based Solutions: The Concepts of "Wilderness," "Rewilding," and "Nature Needs Half" and Their Critical Importance for Nature Based Solutions; The WILD Foundation: Boulder, CO, USA, 2020. Available online: https://wild.org/wpcontent/uploads/2020/09/NatureBasedSolutions-WILD-WSG-WFG-final-19-Aug-20.pdf (accessed on 11 November 2021).

37. World Bank. Biodiversity, Climate Change, and Adaptation: Nature-based Solutions from the World Bank Portfolio; World Bank: Washington, DC, USA. Available online: https:/ / openknowledge.worldbank.org/handle/10986/6216 (accessed on 11 November 2021).

38. Ganapin, D. Rethinking Conservation for People and Nature. WWF News, 2020. Available online: https://bit.ly/3oJKc5T (accessed on 11 November 2021).

39. IUCN/WCPA. Conserving at least 30\% of the Planet by 2030-What should count? IUCN/WCPA, 2021. Available online: https:/ / bit.ly/30Gw4lq (accessed on 11 November 2021).

40. Seddon, N.; Chausson, A.; Berry, P.; Girardin, C.A.J.; Smith, A.; Turner, B. Understanding the value and limits of nature-based solutions to climate change and other global challenges. Philos. Trans. R. Soc. B Biol. Sci. 2020, 375, 20190120. [CrossRef]

41. Stokstad, E. Global efforts to protect biodiversity fall short. Science 2020, 369, 1418. [CrossRef] [PubMed]

42. Fletcher, R.; Massarella, K.; Kothari, A.; Das, P.; Dutta, A.; Büscher, B. A New Future for Conservation. Progressive International 2020. Available online: https:/ / bit.ly/3CD8T90 (accessed on 11 November 2021).

43. Torrance, J.B. Worship, Community, and the Triune God of Grace; Paternoster Press: Carlisle, UK, 1996.

44. Foggin, J.M. Managing Shared Natural Heritages: Towards More Participatory Models of Protected Area Management in Western China. J. Int. Wildl. Law Policy 2014, 17, 130-151. [CrossRef]

45. Raworth, K. Doughnut Economics: Seven Ways to Think Like a 21st-Century Economist; Chelsea Green Publishing: Hartford, VT, USA, 2017.

46. Martin, A. Just Conservation: Biodiversity, Wellbeing and Sustainability; Routledge: New York, NY, USA, 2017.

47. Dowie, M. Conservation Refugees: The Hundred-Year Conflict between Global Conservation and Native Peoples; MIT Press: Cambridge, MA, USA, 2009.

48. Farvar, T.; Borrini-Feyerabend, G.; Campese, J.; Jaeger, T.; Jonas, H.; Stevens, S. Whose 'Inclusive' Conservation? Policy Brief of the ICCA Consortium; The ICCA Consortium and Cenesta: Tehran, Iran, 2018. Available online: https://www.iccaconsortium.org/ index.php/2018/11/03/icca-consortium-policy-brief-no-5/ (accessed on 11 November 2021).

49. Kothari, A.; Corrigan, C.; Jonas, H.; Neumann, A.; Shrumm, H. Recognising and Supporting Territories and Areas Conserved by Indigenous Peoples and Local Communities: Global Overview and National Case Studies; Technical Series; Secretariat of the CBD, ICCA Consortium, Kalpavriksh, Natural Justice: Montreal, QC, Canada, 2012; Volume 64.

50. Cariño, J.; Whitmore, A.; Chepkorir, M.; Bracegirdle, C. How to Bend the Curve of Biodiversity Loss. New Internationalist, 30 September 2020. Available online: https:/ / bit.ly/3HCltsK (accessed on 11 November 2021).

51. Whitehead, J.; Kidd, C.; Perram, A.; Tugendhat, H.; Kenrick, J. Transforming conservation-A rights-based approach. Forest Peoples Programme, 2019. Available online: https:/ / bit.ly/3DzTrfj (accessed on 11 November 2021).

52. Hill, R.; Díaz, S.; Pascual, U.; Stenseke, M.; Molnár, Z.; Van Velden, J. Nature's contributions to people: Weaving plural perspectives. One Earth 2021, 4, 910-915. [CrossRef]

53. Pascual, U.; Adams, W.; Diaz, S.; Lele, S.; Mace, G.M.; Turnhout, E. Biodiversity and the challenge of pluralism. Nat. Sustain. 2021, 4, 567-572. [CrossRef]

54. Moore, K.D. Great Tide Rising: Towards Clarity and Moral Courage in a Time of Planetary Change; Counterpoint: Berkeley, CA, USA, 2016.

55. Mackenzie, J.S.; Jeggo, M. The One Health Approach—Why Is It So Important? Trop. Med. Infect. Dis. 2019, 4, 88. [CrossRef] [PubMed]

56. Smith, W. Understanding the changing role of global public health in biodiversity conservation. Ambio 2021, 1-9. [CrossRef]

57. Kettunen, M.; Dudley, N.; Gorricho, J.; Hickey, V.; Krueger, L.; MacKinnon, K.; Oglethorpe, J.; Paxton, M.; Robinson, J.G.; Sekhran, N. Building on Nature: Area-Based Conservation as a Key Tool for Delivering SDGs. IEEP, IUCN WCPA, The Nature Conservancy, The World Bank, UNDP, Wildlife Conservation Society and WWF, 2021. Available online: https://bit.ly/3HDIr2Q (accessed on 11 November 2021).

58. Charles, A. Communities, Conservation and Livelihoods; IUCN: Gland, Switzerland, 2021. Available online: https://portals.iucn org/library/node/49286 (accessed on 11 November 2021).

59. Manandhar, S.; Joe, N.; Clark, D.A. Making Co-Management Work: A Primer; Johnson-Shoyama Graduate School of Public Policy. Regina, SK, Canada, 2020. Available online: https:/ / bit.ly/3nCaaJ2 (accessed on 11 November 2021).

60. Swiderska, K.; Argumedo, A.; Song, Y.; Rastogi, A.; Gurung, N.; Wekesa, C.; Li, G. Indigenous Knowledge and Values: Key for Nature Conservation; IIED: London, UK, 2021. Available online: https:// pubs.iied.org/20351iied (accessed on 11 November 2021).

61. West, S.; Haider, L.J.; Stålhammar, S.; Woroniecki, S. A relational turn for sustainability science? Relational thinking, leverage points and transformations. Ecosyst. People 2020, 16, 304-325. [CrossRef]

62. Schwartz, S.H. Universals in the Content and Structure of Values: Theoretical Advances and Empirical Tests in 20 Countries. Adv. Exp. Soc. Psychol. 1992, 25, 1-65. [CrossRef] 
63. Gorenflo, L.J.; Romaine, S.; Mittermeier, R.A.; Walker-Painemilla, K. Co-occurrence of linguistic and biological diversity in biodiversity hotspots and high biodiversity wilderness areas. Proc. Natl. Acad. Sci. USA 2012, 109, 8032-8037. [CrossRef]

64. Stepp, J.R.; Castaneda, H.; Cervone, S. Mountains and Biocultural Diversity. Mt. Res. Dev. 2005, 25, 223-227. [CrossRef]

65. Maffi, L. Linguistic, Cultural and Biological Diversity. Annu. Rev. Anthropol. 2005, 34, 599-617. [CrossRef]

66. Loh, J.; Harmon, D. A global index of biocultural diversity. Ecol. Indic. 2005, 5, 231-241. [CrossRef]

67. Sobrevila, C. The Role of Indigenous Peoples in Biodiversity Conservation: The Natural but Often Forgotten Partners; The World Bank: Washington, DC, USA, 2008. Available online: https:/ / bit.ly/3nvQIOd (accessed on 11 November 2021).

68. Büscher, B.; Fletcher, R. The Conservation Revolution: Radical Ideas for Saving Nature Beyond the Anthropocene; Verso Books: Brooklyn, New York, NY, USA, 2020.

69. Büscher, B.; Fletcher, R.; Brockington, D.; Sandbrook, C.; Adams, W.M.; Campbell, L.; Corson, C.; Dressler, W.; Duffy, R.; Gray, N.; et al. Half-Earth or Whole Earth? Radical ideas for conservation, and their implications. Oryx 2017, 51, 407-410. [CrossRef]

70. Stuart, S.N.; Archibald, G.W.; Ball, J.; Berry, R.J.; Emmerich, S.D.; Evans, D.M.; Flenley, J.R.; Gaston, K.J.; Given, D.R.; Gosler, A.G.; et al. Conservation Theology for Conservation Biologists- a Reply to David Orr. Conserv. Biol. 2005, 19, 1689-1692. [CrossRef]

71. Costanza, R.; D'Arge, R.; De Groot, R.; Farber, S.; Grasso, M.; Hannon, B.; Limburg, K.; Naeem, S.; O’Neill, R.V.; Paruelo, J.; et al. The Value of the World's Ecosystem Services and Natural Capital. Nature 1997, 387, 253-260. [CrossRef]

72. Robert, K.W.; Parris, T.M.; Leiserowitz, A.A. What is Sustainable Development? Goals, Indicators, Values, and Practice. Environ. Sci. Policy Sustain. Dev. 2005, 47, 8-21. [CrossRef]

73. Van Houtan, K.S.; Northcott, M.S. Diversity and Dominion: Dialogues in Ecology, Ethics, and Theology; Cascade Books: Eugene, OR, USA, 2010.

74. Bavikatte, S.K. Stewarding the Earth. Rethinking Property and the Emergence of Biocultural Rights; Oxford University Press: New Delhi, India, 2014.

75. Bavikatte, K.S.; Bennett, T. Community stewardship: The foundation of biocultural rights. J. Hum. Rights Environ. 2015, 6, 7-29. [CrossRef]

76. Pope Francis. Encyclical Letter Laudato Si' of the Holy Father Francis on Care for Our Common Home. Vatican, 2015. Available online: https: / bit.ly/32izAn3 (accessed on 11 November 2021).

77. Pope Francis Cites Work of IIPP Director Mariana Mazzucato in Latest Book. UCL Institute for Innovation and Public Purpose, 2020. Available online: https:/ / bit.ly /30JqLBG (accessed on 16 July 2021).

78. Jenkins, W.; Chapple, C.K. Religion and Environment. Annu. Rev. Environ. Resour. 2011, 36, 441-463. [CrossRef]

79. Society for Conservation Biology. Christianity and Conservation Fact Sheet. 2008. Available online: https://bit.ly/3CtnEv2 (accessed on 11 November 2021).

80. Religion and Conservation Biology Working Group. Guidelines for Interacting with Faith-Based Leaders and Communities; Society for Conservation Biology: Washington, DC, USA, 2018. Available online: https:/ / bit.ly/3FwDOG2 (accessed on 11 November 2021).

81. Clatworthy, J. Religious and Secular Concern for the Environment (JRI Briefing Paper, no. 39); John Ray Initiative: Gloucester, UK, 2019. Available online: https://jri.org.uk/religious-and-secular-concern-for-the-environment/ (accessed on 11 November 2021).

82. Verschuuren, B.; NcNeely, J.; Oviedo, G.; Wild, R. Sacred Natural Sites: Conserving Nature and Culture; Routledge: Oxford, UK, 2012.

83. Newell, B.R.; McDonald, R.I.; Brewer, M.; Hayes, B.K. The Psychology of Environmental Decisions. Annu. Rev. Environ. Resour. 2014, 39, 443-467. [CrossRef]

84. Chuang, F.; Manley, E.; Petersen, A. The role of worldviews in the governance of sustainable mobility. Proc. Natl. Acad. Sci. USA 2020, 117, 4034-4042. [CrossRef] [PubMed]

85. Haraway, D. When Species Meet; University of Minnesota Press: Minneapolis, MN, USA, 2008.

86. Harvey, D. Spaces of Hope; University of California Press: Berkeley, CA, USA, 2000.

87. Foggin, M.; Cabrera, L. Achieving Sustainable Development with Equity in an Era of Globalisation; Recognizing and Respecting Local Communities and Indigenous Peoples for Creating the Future We Want; Plateau Perspectives, Policy Brief No. 3. Plateau Perspectives: Bishkek, Kyrgyzstan, 2020. [CrossRef]

88. Ialenti, V. The Art of Pondering Earth's Distant Future. Scientific American. 2021. Available online: https://bit.ly/3qUs7or (accessed on 11 November 2021).

89. Pearson, K.R.; Backman, M.; Grenni, S.; Moriggi, A.; Pisters, S.; de Vrieze, A. Arts-Based Methods for Transformative Engagement: A Toolkit; SUSPLACE: Wageningen, The Netherlands, 2018. Available online: https:/ / edepot.wur.nl/441523 (accessed on 11 November 2021).

90. Phillips, J.S. The rights of indigenous peoples under international law. Glob. Bioeth. 2015, 26, 120-127. [CrossRef]

91. John Knox finishes historic mandate as Special Rapporteur on the Environment and Human Rights. IUCN News, 2018. Available online: https: / / bit.ly /3oJbt8t (accessed on 11 November 2021).

92. Tauli-Corpuz, V.; Alcorn, J.; Molnar, A.; Healy, C.; Barrow, E. Cornered by PAs: Adopting rights-based approaches to enable cost-effective conservation and climate action. World Dev. 2020, 130, 104923. [CrossRef]

93. Zaitchik, A. How Conservation Became Colonialism. Foreign Policy, 16 July 2018. Available online: https:/ / foreignpolicy.com/20 18/07/16/how-conservation-became-colonialism-environment-indigenous-people-ecuador-mining/ (accessed on 11 November 2021).

94. Domínguez, L.; Luoma, C. Decolonising Conservation Policy: How Colonial Land and Conservation Ideologies Persist and Perpetuate Indigenous Injustices at the Expense of the Environment. Land 2020, 9, 65. [CrossRef] 
95. Schmidt-Vogt, D.; Foggin, M.; Hergarten, D.S.-V.M.F.A.C. Strengthening Mountain Societies in Central Asia in a Context of Multidimensional Change. Mt. Res. Dev. 2016, 36, 380-383. [CrossRef]

96. Garnett, S.T.; Burgess, N.D.; Fa, J.E.; Fernández-Llamazares, Á.; Molnár, Z.; Robinson, C.J.; Watson, J.E.M.; Zander, K.K.; Austin, B.; Brondizio, E.S.; et al. A spatial overview of the global importance of Indigenous lands for conservation. Nat. Sustain. 2018, 1, 369-374. [CrossRef]

97. Armitage, D.; Mbatha, P.; Muhl, E.; Rice, W.; Sowman, M. Governance principles for community-centered conservation in the post-2020 global biodiversity framework. Conserv. Sci. Pract. 2020, 2, 1-18. [CrossRef]

98. Borrini-Feyerabend, G.; Pimbert, M.; Farvar, M.T.; Kothari, A.; Renard, Y. Sharing Power. Learning by Doing in Co-Management of Natural Resources throughout the World; IIED, IUCN, CEESP, CMWG, Cenesta: Tehran, Iran, 2004. Available online: https: / / pubs.iied.org/g01089 (accessed on 11 November 2021).

99. Pimbert, M.P. Democratizing knowledge and ways of knowing for food sovereignty, agroecology, and biocultural diversity. In Food Sovereignty, Agroecology and Biocultural Diversity; Routledge: Oxfordshire, UK, 2017; pp. 259-321. Available online: https:/ /library.oapen.org/handle/20.500.12657/40149 (accessed on 11 November 2021).

100. Brugnach, M.; Craps, M.; Dewulf, A. Including indigenous peoples in climate change mitigation: Addressing issues of scale, knowledge and power. Clim. Change 2014, 140, 19-32. [CrossRef]

101. Shigaeva, J.; Hagerman, S.; Zerriffi, H.; Hergarten, C.; Isaeva, A.; Mamadalieva, Z.; Foggin, M. Decentralizing Governance of Agropastoral Systems in Kyrgyzstan: An Assessment of Recent Pasture Reforms. Mt. Res. Dev. 2016, 36, 91-101. [CrossRef]

102. Marshall, G. Nesting, Subsidiarity, and Community-based environmental Governance beyond the Local Scale. Int. J. Commons 2007, 2, 75-97. [CrossRef]

103. Martinez de Anguita, P.; Martín, M.Á.; Clare, A. Environmental Subsidiarity as a Guiding Principle for Forestry Governance: Application to Payment for Ecosystem Services and REDD+ Architecture. J. Agric. Environ. Ethics 2014, 27, 617-631. [CrossRef]

104. McGinnis, M.D.; Ostrom, E. Social-ecological system framework: Initial changes and continuing challenges. Ecol. Soc. 2014, 19, 30. [CrossRef]

105. Ostrom, E. Background on the Institutional Analysis and Development Framework. Policy Stud. J. 2011, 39, 7-27. [CrossRef]

106. Ostrom, E. Nested externalities and polycentric institutions: Must we wait for global solutions to climate change before taking actions at other scales? Econ. Theory 2012, 49, 353-369. [CrossRef]

107. Sarmiento, F.O. Key Issues for Mountain Areas. Mt. Res. Dev. 2006, 26, 298-300. [CrossRef]

108. Foggin, J.M. Conservation Issues: Mountain Ecosystems. In Reference Module in Earth Systems and Environmental Sciences; Elsevier: Amsterdam, The Netherland, 2016. [CrossRef]

109. Hull, V.; Liu, J. Telecoupling: A new frontier for global sustainability. Ecol. Soc. 2018, 23, 41. [CrossRef]

110. Wymann von Dach, S.; Bachmann, F.; Borsdorf, A.; Kohler, T.; Jurek, M.; Sharma, E. (Eds.) Investing in Sustainable Mountain Development: Opportunities, Resources and Benefits; Centre for Development and Environment (CDE), University of Bern, with Bern Open Publishing (BOP): Bern, Switzerland, 2016. Available online: https://boris.unibe.ch/74058/ (accessed on 11 November 2021).

111. Burgass, M.J.; Larrosa, C.; Tittensor, D.P.; Arlidge, W.N.S.; Caceres, H.; Camaclang, A.; Hampton, S.; McLaverty, C.; Nicholson, E.; Muposhi, V.K.; et al. Three key considerations for biodiversity conservation in multilateral agreements. Conservation Letters. 2021, 14, e12764. [CrossRef]

112. Berkes, F. Rethinking Community-Based Conservation. Conserv. Biol. 2004, 18, 621-630. [CrossRef]

113. Maffi, L.; Woodley, E. Biocultural Diversity Conservation: A Global Sourcebook; Earthscan: London, UK; Washington, DC, USA, 2010.

114. Posey, D. Intellectual Property Rights: And Just Compensation for Indigenous Knowledge. Anthr. Today 1990, 6, 13. [CrossRef]

115. Harmon, D. Light of Our Differences: How Diversity in Nature and Culture Makes Us Human; Smithsonian Institution Press: Washington, DC, USA, 2002.

116. Carlson, T.J.S.; Maffi, L. Ethnobotany and Conservation of Biocultural Diversity; New York Botanical Garden Press: Bronx, NY, USA, 2004.

117. Kassam, K.-A.S. Biocultural Diversity and Indigenous Ways of Knowing: Human Ecology in the Arctic; University of Calgary Press: Calgary, AB, Canada, 2009.

118. Kassam, K.-A. Viewing Change Through the Prism of Indigenous Human Ecology: Findings from the Afghan and Tajik Pamirs. Hum. Ecol. 2009, 37, 677-690. [CrossRef]

119. Redford, K.H. The Ecologically Noble Savage. Cult. Surv. Q 1991, 15, 46-48. Available online: https:/ /www.culturalsurvival.org/ publications / cultural-survival-quarterly / ecologically-noble-savage (accessed on 11 November 2021).

120. Ellingson, T. The Myth of the Noble Savage; University of California Press: London, UK, 2001.

121. Diamond, J. Collapse: How Societies Choose to Fail or Succeed; Penguin Group: New York, NY, USA, 2005.

122. Sajeva, G. When Rights Embrace Responsibilities: Biocultural Rights and the Conservation of Environment; Oxford University Press: New Delhi, India, 2018.

123. Sacks, J. The Dignity of Difference: How to Avoid the Clash of Civilizations, 2nd ed.; Continuum: London, UK, 2003.

124. Harrison, L.E.; Huntington, S.P. (Eds.) Culture Matters: How Values Shape Human Progress; Basic Books: New York, NY, USA, 2000.

125. A Rocha International, WEA Creation Care Task Force, and Creation Care Task Force. An Evangelical Call to Action on Biodiversity. 2020. Available online: https:/ / www.weacreationcare.org/call-to-action-on-biodiversity (accessed on 11 November 2021). 
126. ICCA Consortium. Territories of Life: 2021 Report. ICCA Consortium. Available online: www.report.territoriesoflife.org (accessed on 11 November 2021).

127. International Network of Mountain Indigenous Peoples (INMIP). The Suusamyr Declaration. 2018. Available online: https: / / pubs.iied.org/g04342 (accessed on 11 November 2021).

128. Ogar, E.; Pecl, G.; Mustonen, T. Science Must Embrace Traditional and Indigenous Knowledge to Solve Our Biodiversity Crisis. One Earth 2020, 3, 162-165. [CrossRef]

129. Corrigan, C.; Hay-Edie, T. A Toolkit to Support Conservation by Indigenous Peoples and Local Communities: Building Capacity and Sharing Knowledge for Indigenous Peoples' and Community Conserved Territories and Areas (ICCAs); UN Environment Programme World Conservation Monitoring Centre (UNEP-WCMC): Cambridge, UK, 2013.

130. Townsend, J.; Moola, F.; Craig, M.-K. Indigenous Peoples are critical to the success of nature-based solutions to climate change. FACETS 2020, 5, 551-556. [CrossRef]

131. Hanspach, J.; Haider, L.J.; Oteros-Rozas, E.; Olafsson, A.S.; Gulsrud, N.M.; Raymond, C.M.; Torralba, M.; Martín-López, B.; Bieling, C.; García-Martín, M.; et al. Biocultural approaches to sustainability: A systematic review of the scientific literature. People Nat. 2020, 2, 643-659. [CrossRef]

132. Swiderska, K.; Argumedo, A.; Pimbert, M. Biocultural Heritage Territories: Key to Halting Biodiversity Loss; IIED: London, UK, 2020. Available online: https:/ / pubs.iied.org/17760iied (accessed on 11 November 2021).

133. Giuliani, A.; van Oudenhoven, F.; Mubalieva, S. Agricultural Biodiversity in the Tajik Pamirs A Bridge Between Market Development and Food Sovereignty. Mt. Res. Dev. 2011, 34, 16-26. [CrossRef]

134. Martín-López, B.; Balvanera, P.; Manson, R.; Mwampamba, T.H.; Norström, A. Contributions of place-based social-ecological research to address global sustainability challenges. Glob. Sustain. 2020, 3, e21. [CrossRef]

135. Carson, R. The Sense of Wonder; Harper and Row Publishers: New York, NY, USA, 1965. 